\title{
11 True Cost Principles in Public Policy
}

\author{
How Schools and Local Government \\ Bring Value to Procurement
}

\author{
Paula A. Daniels
}

\section{Food Production and Social Values: A Mid-Century Disconnect}

It has been a half century since the 1968 speech that US Senator Robert Kennedy gave in which he spoke of the intellectual fallacy of measuring a nation's success by the economic yardstick of the Gross National Product. "Too much and for too long," he said, "we seemed to have surrendered personal excellence and community values in the mere accumulation of material things" (Kennedy, 1968). He went on to list the limitations of measuring success by those prevalent economic indicators:

Our Gross National Product...counts air pollution and cigarette advertising, and ambulances to clear our highways of carnage. It counts special locks for our doors and the jails for the people who break them. It counts the destruction of the redwood and the loss of our natural wonder in chaotic sprawl. It counts napalm and counts nuclear warheads and armored cars for the police to fight the riots in our cities....Yet the gross national product does not allow for the health of our children, the quality of their education or the joy of their play. It does not include the beauty of our poetry or the strength of our marriages, the intelligence of our public debate or the integrity of our public officials. It measures neither our wit nor our courage, neither our wisdom nor our learning, neither our compassion nor our devotion to our country, it measures everything in short, except that which makes life worthwhile.

(emphasis added)

His challenge to the nation arose from the urgent core of his galvanizing role as a leading progressive voice in a society experienceing a then unprecedented level of cultural and political upheaval (McLaughlin, 2014).

Senator Kennedy spoke of other issues during his landmark speech, including the value of protest. The power of protest has carried through to 2020: recent events in the USA relating to racial inequities have seen large-scale protest participation, including the presence of mayors and other civic or political leaders. However, Kennedy's caution about the limited utility of society's heavy reliance on the Gross Domestic Product (GDP) has not experienced the same traction. 
Or has it? If not through an explicit rejection of the GDP as a singular measure, a more subtle but effective version of success measurement in the food system might be underway: in the US school food system.

\section{The Past is Prologue}

As with our prevailing commercialized food system, the entrenchment of Gross National Product as a primary measure of progress is considered to be an outgrowth of World War II political culture (Debroy and Kapoor, 2019; Costanza et al., 2014). The current unhealthy state of the US food system is often attributed to mid-Century economics and the Cold War era of American economic expansion, a political layer built on the post-World War II use of military chemicals for farmland fertilizer, ushering in the age of agricultural industrialization (Pollan, 2006). The US National School Lunch Program (NSLP) - the second largest nutrition assistance program in the United States (United States Department of Agriculture Economic Research Service, 2019) — was also an outgrowth of World War II. Signed into law by President Harry Truman in 1946, it was intended to increase demand for agricultural commodities and to provide nutrition to lower income school children. Today, it is in 94\% of US schools, spends about $\$ 13$ billion annually, and serves around 30 million children (United States Department of Agriculture Economic Research Service, 2019) in nearly 100,000 public and private K-12 schools across the USA (United States Department of Agriculture Economic Research Service, 2019). The volume of food purchased makes the school system a large component of the $\$ 120$ billion annual institutional food service market (United States Department of Agriculture Economic Research Service, 2017).

But the NSLP operates on a cost reimbursement basis, and in 2019 the average reimbursement rate was set at between $\$ 3.11$ and $\$ 3.51$ per meal, for students at or below established poverty levels (School Nutrition Association, 2020). At those prices, school districts have tended to source highly commoditized, price subsidized food products. One could argue that in the early decades of the program, school food contributed to the exacerbation of the singular commercial value of economic scale, carrying out the Cold War era imperative.

The era which fostered the rise of the US school food program was a turning point in the American food system, ushering in a precipitous decline in farm populations ("a 'free fall' situation leading to "trauma," according to a former US Department of Agriculture [USDA] demographer, Calvin Beale) (United States Department of Agriculture, 1981) as farms consolidated toward large scale operations. With the shift toward highly consolidated, vertically integrated and industrially efficient agriculture came a rise in obesity (Centers for Disease Control and Prevention, 2020), a loss of agricultural biodiversity, and a rise in nitrate pollution and greenhouse gas emissions owing to concentrated methods of farming and animal rearing (Lilliston, 2019).

Before that point, the national obesity rate was about $12 \%$. (Ogden et al., 2010). There was more diversification of farm ownership and type: around 40\% 
of the US workforce was in agriculture, and there were over six million farms (Dimitri et al., 2005). By contrast, in the second half of the twentieth century, the obesity rate climbed to $60 \%$, and agriculture became consolidated: there is now less than $2 \%$ of the workforce in agriculture, and fewer than two million farms, while average farm size has increased by over $60 \%$, and agricultural output has tripled and become increasingly specialized (Dimitri et al., 2005). In the meat sector over that same time frame, meat supply consolidated into just four companies (Ostland, 2011). Ten multinational companies now control most of the world's food system (Taylor, 2016).

For too long the yardstick of success, particularly in terms of public investment, was measured in terms of more volume production, more dollars in returns, and more delivery of calories, without regard to the quality of nutrition or the quality of the relationships along the food supply chain.

As pointed out by Robert Gottlieb and Anupama Joshi in their book Food Justice, by being bound to the agriculture commodity program, the school food program was part of the problem (Gottlieb and Joshi, 2017). Despite an interest in nutritional goals in the 1970s, the politics of the 1980s led to a stigmatization of poverty assistance programs, and the school food program was no exception. The businessorientated ethos of President Reagan and his Administration also led to infamous characterizations of ketchup as a vegetable; it was a regulatory move to ensure that the commercial product fit within the short-sighted administrative dietary guidelines of the time and could be sold widely throughout the massive federal school food program. The era also saw a rise in vending machines in schools, stuffed with junk food and sugary sodas, followed by corporate sponsorships from food companies such as the American beverage giants Coca-Cola and PepsiCo (Gottlieb and Joshi, 2017; Levine, 2008), succumbed to by financially desperate administrators who were operating under the thumb of federal reimbursement guidelines. The school food program wielded considerable influence on food economics.

Not surprisingly, advocacy for food system reform, which has been on the rise in the past few decades, has often included school food as a key policy area. First Lady Michelle Obama elevated the issue area as a priority with a particular focus on nutrition; her initiatives included the Healthy Hunger Free Kids Act (HHFKA) signed by President Obama in 2010. HHFKA authorized the USDA to make significant reforms to the nutrition guidelines for the school lunch program, for the first time in decades, and included funding for local farm to school and garden programs. This effort became politicized, however, and the subsequent federal administration rolled back a number of the key changes of the HHFKA (Green and Piccoli, 2019).

\section{Embedding Community Values in Institutional Food at a Municipal Level}

The federal politics of food, and the regulatory seesaw of the USDA under different administrations, has led many food system advocates and political leaders toward recognition of the role of municipal governments as a key area for 
creating change in the status quo. Indeed, it is a unit of governance that seems increasingly more effective at responding to the needs of modern populations, organized as they are in intensified urban centers. As Benjamin Barber observed in his book If Mayors Ruled the World: Dysfunctional Nations, Rising Cities: "We have come full circle in the city's epic history (Barber, 2013). Humankind began its march to politics and civilization in the polis - the township. It was democracy's original incubator." It might again be its best hope, particularly in times of crisis.

In the food system, the Milan Urban Food Policy Pact was launched in 2014, driven by the fact that " $[\mathrm{m}]$ ore than 50 percent of the world's population currently lives in urban areas - a proportion that is projected to increase to almost 70 percent by 2050 - and ensuring the right to food for all citizens, especially the urban poor, is key to promoting sustainable and equitable development." The Pact acknowledges that:

...current food systems are being challenged to provide permanent and reliable access to adequate, safe, local, diversified, fair, healthy and nutrient rich food for all; and that the task of feeding cities will face multiple constraints posed by inter alia, unbalanced distribution and access, environmental degradation, resource scarcity and climate change, unsustainable production and consumption patterns, and food loss and waste.

("Milan Urban Food Policy Pact," 2015)

The signatory cities to the Pact commit to, among many other things:

- Develop sustainable food systems that are inclusive, resilient, safe and diverse, that provide healthy and affordable food to all people in a human rights-based framework, that minimize waste and conserve biodiversity while adapting to and mitigating impacts of climate change; and

- Encourage interdepartmental and cross-sector coordination at municipal and community levels, working to integrate urban food policy considerations into social, economic and environment policies, programs and initiatives, such as, inter alia, food supply and distribution, social protection, nutrition, equity, food production, education, food safety and waste reduction.

Over 200 mayors around the world have signed the Milan Urban Food Policy Pact (www.milanurbanfoodpolicypact.org/text) since its launch, but as of 2020 only nine of them were US city mayors. However, increasingly, many US cities are seeing the establishment of food policy councils, which in many regions have served the role of food system advocacy as well as government accountability. The Johns Hopkins Center for a Livable Future describes food policy councils as "networks that represent multiple stakeholders and that are either sanctioned by a government body or exist independently of government, and address food-related issues and needs within a city, county, state, tribal, 
multi-county or other designated region." (Food Policy Networks, n.d.-a) Their database of food policy councils shows them at over 300 in North America (Food Policy Networks, n.d.-b). For many of the food policy councils, school food is a top priority (Bassarab, 2019).

Among the more prominent food policy councils is the Los Angeles Food Policy Council (LAFPC), launched in 2011 as an initiative of Mayor Villaraigosa of Los Angeles, in the second largest city in the USA and the 23rd largest world city. It was launched with a mandate developed by a task force, to advance 55 action steps in six priority areas, directed toward the goal of building a more sustainable and equitable regional food system in the Los Angeles region of southern California (Los Angeles Food Policy Task Force, 2010).

The well-staffed, municipal government supported council gave rise to the Good Food Purchasing Program (the Program), adopted by the City of Los Angeles and Los Angeles Unified School District (LAUSD) in 2012. It was developed through an extensive multi-sector, interdisciplinary, multi-stakeholder collaboration and review process within the LAFPC. The Program provides a metric based, flexible framework that is the basis for a feedback and rating tool for its enrolled institutions, and it embeds five core community values in its Program design.

\section{The Good Food Purchasing Program as a True Cost Influencer}

As mentioned, each year food service institutions - from hospitals to jails to school districts-spend nearly $\$ 120$ billion on food. Yet institutions rarely have the information, resources, or expertise that they need to align purchasing with community values, and local communities lack the data or tools that they need to build public support for aligning purchasing with their values and achieving policy change. For example, the adoption of the Good Food Purchasing Program has served as a basis for municipal council resolutions which explicitly recognized The Good Food Purchasing Program as a lever to address the issues identified in its five core values, along with other issues such as food justice and equity (Board of Commissioners of Cook County, 2018; City of Boston in City Council, 2019).

The Good Food Purchasing Program provides the information and resources that institutions and communities need to break through the murkiness of informational opacity. Similar to how the Leadership in Energy and Environmental Design (LEED) (United States Green Building Council, n.d.) certification works in rating energy efficiency and environmental design in buildings, the Program combines a unique, flexible framework for values-based purchasing with metric-based targets; the staff of the Center provide analysis of the purchasing data against that rubric, and review, verify and rate the compliance levels of participating institutions.

Key aspects of the Program include:

- Program enrollment through organizational collaboration toward shared goals in partnership with municipal leaders and food service providers; 
- A rating system for institutions which provides feedback and accountability, helping institutions redirect food budgets towards more sustainable suppliers and those that adhere to fair labor practices, and providing a basis for transparency and accountability;

- A point system which offers institutions a flexible roadmap toward values based purchasing, through a metric based, tiered structure driving institutional purchasing toward five food system values around which the Program is deeply architected and designed;

- The rating system includes collection of purchasing data from an enrolled institution, for evaluation against the five value categories; and

- The five core value categories are: local economies, environmental sustainability, fair labor, animal welfare, and nutritional health.

As an outcome, the Program promotes the purchase of more sustainably produced food from local economies, especially small, mid-sized, and historically disadvantaged farms and food processing operations, which results in production returns at a more regional and local level, ensures that suppliers' workers are offered safe and healthy working conditions and fair compensation, that livestock receives healthy and humane care, and that consumers-foremost school children, patients, the elderly-enjoy better health and well-being, thanks to higher quality nutritious meals.

Within one year of the Program adoption at LAUSD in 2012, the institution, with its $\$ 120$ million per year food budget, achieved the success that its design was intended to promote: local sourcing of produce rose from an average of $10 \%$ per year to an average of $60 \%$ per year, redirecting $\$ 12$ million to the local food economy. As a result, some 150 new well-paid food chain jobs

\section{VALUES SHAPE POLICY}

THE GOOD FOOD PURCHASING PROGRAM IS A COMMITMENT TO:

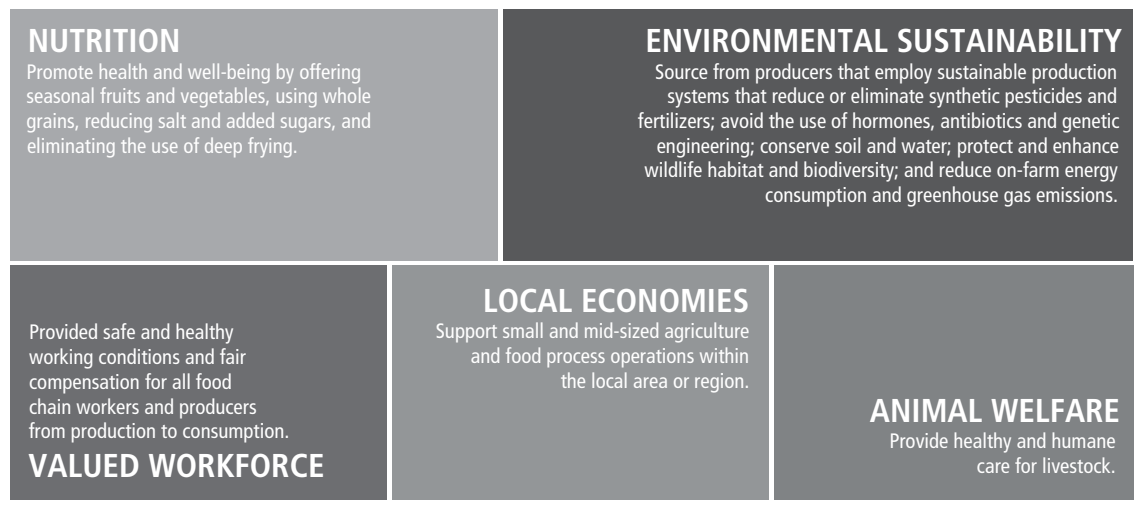

Figure 11.1 Good Food Purchasing Program values. 


\section{Daniels}

were created in Los Angeles County, including food processing, manufacturing, and distribution. In the ensuing years, 160 truck drivers in LAUSD's supply chain received higher wages and improved working conditions.

Owing to the immediate success of the Program at LAUSD, interest in adoption by other cities was piqued, initially through the Food Policy Task Force of the US Conference of Mayors (convened by Mayor Villaraigosa), and eventually to greater effect through alliances with labor, environmental, and food system advocacy organizations. In 2015 the Program was spun off from the LAFPC and became the program of the Center for Good Food Purchasing, established to advance the national expansion of the Program. As at July 2020, over 50 municipal institutions in 20 major cities across the USA were enrolled in the Program, over 2.5 million students were being served under the scheme, and over $\$ 1$ billion in institutional purchasing was being analyzed and rated by the Center.

The Program is the first procurement model designed to elevate food service (whether in municipal agencies/departments, universities, schools and/or hospitals) as a transformative tool, using the purchasing power of these institutions to support the five food system values of local economies, environmental sustainability, valued workforce, animal welfare, and nutrition in equal measure. Those five core value categories, together with the public accountability structure of the Program itself, are reflective of the ten Elements of Agroecology as defined by the United Nations (Food and Agriculture Organization, n.d.-a; n.d.-b) and align with at least 12 of the 17 of the United Nations Sustainable Development Goals. The systemically holistic Good Food Purchasing Program was favorably recognized in 2018 (FuturePolicy.org, n.d.) by the World Future Council, the Food and Agriculture Organization of the United Nations, and IFOAM Organics International as a Future Policy Scaling Up Agroecology.

The Good Food Purchasing Program, in measuring how enrolled institutions direct their purchasing toward its five value categories, also aligns with the TEEBAgrifood framework (as described elsewhere in this book). In short, the Program can be characterized as True Cost Accounting (TCA) at work in enrolled municipal institutions.

\section{The Power of Procurement}

In his Briefing Note 8 (April 2014), The Power of Procurement: Public Purchasing in Realizing the Right to Food (De Schutter, 2014), UN Special Rapporteur De Schutter recognized that:

Governments have few sources of leverage over increasingly globalized food systems - but public procurement is one of them. When sourcing food for schools, hospitals and public administrations, Governments have a rare opportunity to support more nutritious diets and more sustainable food systems in one fell swoop. 
Procurement is also one of the recommended actions of category five of the Milan Urban Food Policy Pact, which calls for a review of:

...public procurement and trade policy aimed at facilitating food supply from short chains linking cities to secure a supply of healthy food, while also facilitating job access, fair production conditions and sustainable production for the most vulnerable producers and consumers, thereby using the potential of public procurement to help realize the right to food for all.

(Milan Urban Food Policy Pact, n.d.)

As pointed out by the Union of Concerned Scientists in their 2017 report on the impacts of the Good Food Purchasing Program in Los Angeles, the "benefits of a better supply chain are amplified across institutions and regions" (Mulik and Reinhardt, 2018). The incremental shifts created by the institutions enrolled in the Program show combined totals across institutions of over $\$ 56$ million in supporting local economies, over $\$ 32$ million in supporting fair labor, over $\$ 20$ million toward meat raised without routine use of antibiotics, and an additional $\$ 10$ million supporting environmental sustainability. Some other key achievements of the Program:

- Increase in fruits and vegetables served in enrolled institutions

- Increase in worker wages, including a 40\% wage increase for 320 warehouse workers and truck drivers along LAUSD's supply chain

- In 2017, LAUSD awarded $\$ 70$ million in contracts for chicken produced without routine antibiotics.

- In the Austin, Texas school district, expenditures on organic products tripled over the first two years in the Program.

- Over one school year, Oakland Unified School District reduced its carbon and water footprint by roughly $20 \%$ through sourcing less meat and doubled its purchase of sustainable and humane food products, without increasing costs.

Notably, the ability to increase purchases even more in key value categories has been hampered by the cost of food products that fall within the identified categories of environmental sustainability, fair trade, or humane. Those food products which are certified as, for example, USDA Organic, Fair Trade certified, or Animal Welfare Approved, are sold at a price premium, which reflects the more positive relationship to the environment, labor, or animal welfare than industrially produced foods; in other words, those positively certified food products are closer to "true cost." However, that price premium is difficult for a school district to bear within budgetary constraints.

\section{Incentives for True Cost Food}

As mentioned, school districts have very tight budgets for their food purchases, and the reimbursement amount typically also pays for labor (LAUSD Food 


\section{Daniels}

Service Director, personal interview by Paula Daniels, 2020). The procurement bid process of these large institutions does allow them to obtain reasonable percentages of the value-based food within their budgets, as conveyed to the food service bidders through Requests for Proposals. The value certified food products can be incorporated into vendor bids at a price break made possible owing to the volume of demand, but not yet in quantities sufficient to make larger-scale shifts.

A key recommendation to address this gap is the creation of a financial incentive fund to support the purchase of the more "true cost" foods by municipal food service providers. The fund could be created in a number of ways, including through public-private-philanthropic partnership arrangements that incorporate fund criteria and oversight. Local and state governments could lead the way in developing and directing these financial incentives to the anchor institutions to enable purchasing support for fair wage and climate friendly food production practices, such as soil health.

Based on conversations with food service providers at school districts and other municipal institutions, an additional $\$ 0.15$ to $\$ 0.25$ per meal would provide the ability to purchase food that reflects the true cost of its production in one or more of the value categories (School Food Service Directors of Austin, Minneapolis and San Francisco, personal conversation by Alexa Delwiche, n.d.).

The incentive concept builds on the pioneering local food incentive models already established in Michigan's "10 Cents a Meal for Michigan's Kids \& Farms" (www.tencentsmichigan.org/), New Mexico (New Mexico Department of Health, 2019), Oregon (Kane et al., 2011), and New York (New York State Department of Agriculture and Markets, n.d.; New York State Health Foundation, 2018; New York State, 2019). For example, in Michigan, the state legislature created a 10 Cents Per Meal program in 2017 which provides 10 cents per meal to provide 57 school districts with those extra funds to buy local fruits, vegetables, and dry beans. Since its inception, 121 school districts throughout the state have applied. According to the 10 Cents Per Meal 2018-2019 legislative report, school food service directors reported an increase in the variety of produce served to students in school meals. The return to the local food economy supported 143 Michigan farms and 20 supply chain business, which also benefited from the advance planning the school food service directors could undertake (Michigan Department of Education, 2019). New Mexico operates its program as a grant program with an annual award of, for example, $\$ 85,000$ for Albuquerque public schools. In Oregon, the state legislature accessed economic development funds for a 7 cents per meal incentive for local food purchases in the school lunch and breakfast programs. A report on two school districts which participated in the program (Ecotrust, n.d.) found that the school districts indeed used the extra amount to leverage the investment to purchase local items "that cost slightly more than items they had previously been purchasing non-locally" and also that "new vendor relationships were formed at both schools", bolstering the local food economy. The report observed: 
Schools can easily funnel the money through a mainline food service distributor, and the more that these companies experience requests for local products, the more likely they are to expand their local purchases and product offerings, with direct implications for the scale and effects of farm to school programming nationwide.

The most generous reimbursement rate, in a program with the most ambitious targets, is in the state of New York, which offers " 25 cents per meal for any district that purchases at least 30 percent ingredients for their school lunch program from New York farms" (New York State Department of Agriculture and Markets, n.d.).

An important next step is expanding this model to other valued attributes of an agroecological food system, including in the incentive criteria that there be proportional purchasing of food that supports environmental sustainability (including climate friendly and humane production practices) and fair labor.

This undertaking could serve as a proof point for the field in a few ways:

- Quantify how much money school districts need to increase Good Food (or True Cost) procurement.

- Demonstrate feasibility of the model to inform future school meal reimbursement policy initiatives at a federal level.

- Evaluate broad-based health outcomes and project changes in long-term health costs.

\section{A Twenty-First-Century Path}

The inclusion of values other than monetary as a measure of success has been taking place over the past decade or so in intricate ways, organization by organization. In our example, school districts and other municipal food service institutions in the US are measuring their success by the point system of the Good Food Purchasing Program and how well they support the five community-based values of the Program. They are measuring what matters, as Senator Kennedy had urged in 1968.

Will this TCA framework for food have the same ripple effect? Will it set the US on a new trajectory toward an agroecological food system? It depends. Whether formally adopted or infused in the decision-making of even more food service entities, measuring progress toward more of what matters will make a difference; indeed, it already has.

\section{References}

Barber, B. (2013). If Mayors Ruled the World: Dysfunctional Nations, Rising Cities, (pp. 328). New Haven, CT: Yale University Press. Available at: www.jstor.org/stable/j. ctt5vksfr.4. 


\section{Daniels}

Bassarab, K.et al. (2019, April 1). Food Policy Council Report 2018. Johns Hopkins Center for a Livable Future, Food Policy Networks. Available at: https://assets.jhsph. edu/clf/mod_clfResource/doc/FPC\%20Report\%202018-FINAL-4-1-19.pdf.

Board of Commissioners of Cook County. (2018). To Adopt the Good Food Purchasing Program. Available at: https://cook-county.legistar.com/LegislationDetail.aspx?ID= 3309826\&GUID=ED1C9BDF-90BD-4355-AB3C-AE1738EC6A38\&Options $=\&$ Search $=$.

Centers for Disease Control and Prevention. (2020). Adult Obesity Facts. Overweight \& Obesity. Centers for Disease Control and Prevention. Available at: www.cdc.gov/ obesity/data/adult.html.

City of Boston in City Council. (2019). An Ordinance Regarding Good Food Purchasing Standards in the City of Boston. Available at: www.boston.gov/sites/default/ files/file/document_files/2019/02/0139.pdf.

Costanza, R.et al. (2014). A Short History of GFP: Moving Towards Better Measures of Human Well-being. The Solutions Journal, (5)1, (pp. 91-97). Available at: www.the solutionsjournal.com/article/a-short-history-of-gdp-moving-towards-better-measuresof-human-well-being.

De Schutter, O. (2014). The Power of Procurement: Public Purchasing in the Service of Realizing the Right to Food. (Briefing Note 08), United Nations. Available at: www. srfood.org/images/stories/pdf/otherdocuments/20140514_procurement_en.pdf.

Debroy, B. and Kapoor, A. (2019). GDP Is Not a Measure of Human Well-Being. CNN. Available at: https://hbr.org/2019/10/gdp-is-not-a-measure-of-human-well-being.

Dimitri, C., Effland, A., \& Conklin, N. (2005). The 20th Century Transformation of U. S. Agriculture and Farm Policy. Economic Information Bulletin, Number 3. United States Department of Agriculture, Economic Research Service. Available at: www. ers.usda.gov/webdocs/publications/44197/13566_eib3_1_.pdf?v=7007.

Ecotrust. (n.d.). The Impact of Seven Cents. Available at: https://ecotrust.org/media/ 7-Cents-Report_FINAL_110630.pdf.

Food and Agriculture Organization of the United Nations. (n.d.-a). 10 Elements of Agroecology. Available at: www.fao.org/agroecology/knowledge/10-elements.

Food and Agriculture Organization of the United Nations. (n.d.-b). Agroecology Knowledge Hub. Available at: www.fao.org/agroecology/home/en.

Food Policy Networks. (n.d.-a). About Us. Available at: www.foodpolicynetworks.org/ about/.

Food Policy Networks. (n.d.-b). Food Policy Council Map. Available at: www.foodpoli cynetworks.org/councils/fpc-map.

FuturePolicy.org. (n.d.). Good Food Purchasing Program. Available at: www.futurepolicy. org/healthy-ecosystems/los-angeles-good-food-purchasing-program.

Gottlieb, R. \& Joshi, A. (2017). Food Justice. (p. 88). Cambridge, MA: The MIT Press.

Green, E. \& Piccoli, S. (2019). Trump Administration Sued Over Rollback of School Lunch Standards. The New York Times, April 3. Available at: www.nytimes.com/ 2019/04/03/us/politics/trump-school-lunch-standards.html.

Kane, D., Kruse, S., Ratcliffe, M.M., Sobell, S.A., \& Tessman, N. (2011). The Impact of Seven Cents. Ecotrust. Available at: https://ecotrust.org/media/7-Cents-Report_ FINAL_110630.pdf.

Kennedy, R. (1968). Remarks at the University of Kansas. John F. Kennedy Presidential Library and Museum. Available at: www.jfklibrary.org/learn/about-jfk/the-kennedyfamily/robert-f-kennedy/robert-f-kennedy-speeches/remarks-at-the-university-ofkansas-march-18-1968. 
Levine, S. (2008). School Lunch Politics. Princeton, NJ: Princeton University Press.

Lilliston, B. (2019). Latest agriculture emissions data show rise of factory farms. Institute for Agriculture and Trade Policy. Available at: www.iatp.org/blog/201904/latestagriculture-emissions-data-show-rise-factory-farms.

Los Angeles Food Policy Task Force. (2010). Good Food For All Agenda. Available at: https://goodfoodlosangeles.files.wordpress.com/2010/07/good-food-full_report_single_ 072010.pdf

McLaughlin, K. (2014). Eight unforgettable ways 1968 made history. CNN, July 31. Available at: www.cnn.com/2014/07/31/us/1968-important-events/index.html.

Michigan Department of Education. (2019). 10 Cents a Meal for School Kids \& Farms: State Pilot Project Overview (2018/2019 Legislative Report). Available at: https://d3n8a 8pro7vhmx.cloudfront.net/tencentsmichigan/pages/26/attachments/original/ 1553192603/10_Cents_a_Meal_2018-2019_Legislative_Report.pdf?1553192603.

Milan Urban Food Policy Pact. (n.d.). Food supply and distribution. MUFPP Recommended actions. Available at: www.milanurbanfoodpolicypact.org/mufpp_food-supplyand-distribution/.

Milan Urban Food Policy Pact. (2015). Milan Urban Food Policy Pact. Available at: www. milanurbanfoodpolicypact.org/wp-content/uploads/2016/06/Milan-Urban-Food-Po licy-Pact-EN.pdf.

Mulik, K. \& Reinhardt, S. (2018). Purchasing Power: How Institutional "Good Food" Procurement Policies Can Shape a Food System That's Better for People and Planet. Union of Concerned Scientists. Available at: www.ucsusa.org/sites/default/files/atta ch/2017/11/purchasing-power-report-ucs-2017.pdf.

New Mexico Department of Health. (2019). Students to Celebrate Farm to School Programs for New Mexico Grow Week. Available at: www.nmhealth.org/news/hea lthy $/ 2019 / 9 /$ ? view $=800$.

New York State. (2019). Governor Cuomo Announces \$1.5 Million Available to School Districts Through State's Farm-To-School Program. Available at: www.gov ernor.ny.gov/news/governor-cuomo-announces-15-million-available-school-districtsthrough-states-farm-school.

New York State Department of Agriculture and Markets. (n.d.). Farm to School. Available at: https://agriculture.ny.gov/farming/farm-school.

New York State Health Foundation. (2018). Issue Brief: Local Lunches: A "Win-Win” for New York State's Farmers and Students. Available at: https://nyshealthfounda tion.org/wp-content/uploads/2018/07/issue-brief-local-lunches-farm-to-school.pdf.

Ogden, C.et al. (2010). Prevalence of Overweight, Obesity, and Extreme Obesity Among Adults: United States, Trends 1960-1962 Through 2007-2009. Centers for Disease Control and Prevention. Available at: www.cdc.gov/nchs/data/hestat/obesi ty_adult_07_08/obesity_adult_07_08.pdf.

Ostland, E. (2011). The Big Four Meat Packers. High Country News, March 21, 2011. Available at: www.hcn.org/issues/43.5/cattlemen-struggle-against-giant-meatpackersand-economic-squeezes/the-big-four-meatpackers-1.

Pollan, M. (2006). What's Eating America. Smithsonian. Available at: https://michaelp ollan.com/articles-archive/whats-eating-america/ .

School Nutrition Association. (2020). School Meal Trends \& Stats. Available at: https:// schoolnutrition.org/aboutschoolmeals/schoolmealtrendsstats/.

Taylor, K. (2016). These Ten Companies Control Everything You Buy. Business Insider, September 28, 2016. Available at: www.businessinsider.com/10-companies-con trol-the-food-industry-2016-9?op=1. 


\section{Daniels}

United States Department of Agriculture. (1981). A Time to Choose: Summary Report on the Structure of Agriculture. Available at: https://archive.org/stream/timetochoosesumm 00unit/timetochoosesumm00unit_djvu.txt.

United States Department of Agriculture. (2019). National School Lunch Program Fact Sheet. Available at: www.fns.usda.gov/nslp/nslp-fact-sheet.

United States Department of Agriculture, Economic Research Service. (2017). Market Segments.

United States Departments of Agriculture Economic Research Service. (2019). National School Lunch Program. Available at: www.ers.usda.gov/topics/food-nutrition-assista nce/child-nutrition-programs/national-school-lunch-program.

United States Green Building Council. (n.d.). LEED Rating System. Available at: www. usgbc.org/leed. 